\title{
STRATEGI IMPLEMENTASI PENGARUSUTAMAAN GENDER BIDANG PENDIDIKAN ISLAM
}

\author{
Mufidah Ch \\ Fakultas Syari' ah UIN Maliki Malang, \\ email: fidah_cholil@yahoo.com
}

Abstract: Islam encourages Moslems to seek for knowledge regardless the area boundary, age, and field of interest. However, the Islamic education in Indonesia has not been able to facilitate men and women to obtain equal education. This gender gap is found in the policy, management, and teaching institutions of Islamic education. This has an impact on learner output, his/her roles and responsibilities in society. Although the President Instruction No. 9/2000, which foreruns the implementation of gender mainstreaming in national development, has been implemented more than a decade, the policy is neither fully understood nor well implemented especially in the field of Islamic education. Gender mainstreaming is still questioned because a number of institutions and relevant parties have not shown serious responses yet to overcome gender gaps in such areas as policy making, management, and learning. Carrying out analytical study on the gender mainstreaming in Islamic education is, therefore, inevitable: i.e. whether or not it has been practiced based on the implementation guidelines of gender mainstreaming in the national development.

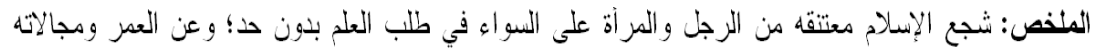

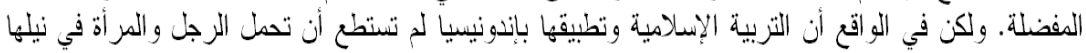

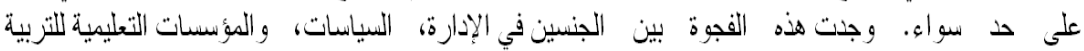

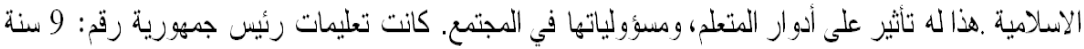

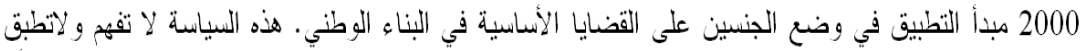

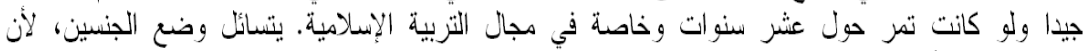

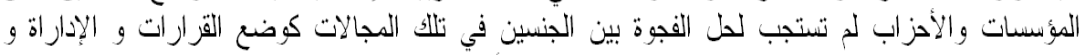

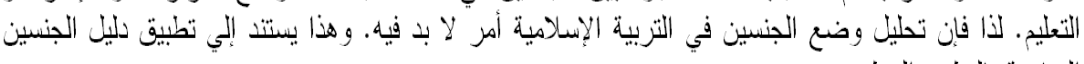

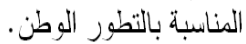

Keywords: Pengarusutamaan gender, Pendidikan Islam, Kementerian Agama RI, Kementerian Pendidikan Nasional, Kebijakan pemerintah/negara. 


\section{PENDAHULUAN}

Diskusi tentang kesenjangan gender bidang pendidikan Islam masih dipandang aktual. Dalam berbagai aspek pendidikan, baik manajemen, pembelajaran, dan peran serta masyarakat masih menunjukkan adanya bias gender. Kebijakan bidang pendidikan sesungguhnya telah mengalami perubahan pasca dikeluarkannya Inpres No. 9 Tahun 2000 tentang Pengarusutamaan Gender dalam Pembangunan Nasional yang diikuti pula oleh Rencana Strategis Kementerian Pendidikan Nasional sejak tahun 2003, namun implementasinya pada lembaga-lembaga pendidikan masih ditemukan kebijakan internal yang belum responsif gender.

Berdasarkan data Kementerian Agama RI tahun 2009 bahwa guru agama di Indonesia terdiri atas laki-laki 48,67\% dan perempuan mencapai $51,33 \%$. Tingginya jumlah guru perempuan ini lebih banyak terdapat pada tingkat pendidikan dasar. Hal ini disebabkan oleh pandangan bahwa peran guru tingkat pendidikan dasar lebih dekat dengan pengasuhan anak (peran reproduksi) dalam rumah tangga. Meskipun jumlah guru laki-laki lebih kecil, jumlah kepala sekolah masih didominasi oleh laki-laki yang disebabkan oleh pandangan bahwa laki-laki lebih pantas memimpin daripada perempuan sehingga sejumlah guru yang memiliki dedikasi tinggi dan prestasi dalam mengajar dikalahkan oleh anggapan bias gender tersebut. ${ }^{1}$

Kesetaraan gender dapat diketahui melalui indikator yang meliputi akses, partisipasi, kontrol, dan manfaat. Dengan demikian, jika keempat indikator tersebut masih bermasalah, diskriminasi gender masih terjadi dalam pendidikan. Secara umum diskriminasi gender dalam pendidikan dapat diuraikan sebagai berikut. Pertama, terdapat keterbatasan bagi perempuan untuk menjadi tenaga pengajar terutama pada tingkat SLTAke atas. Hal tersebut menyebabkan proses pembelajaran tidak berorientasi pada kesetaraan gender. Akses bagi perempuan terhadap jurusan-jurusan ilmu dasar seperti fisika, biologi, teknologi dan industri masih rendah. Hal ini bukan disebabkan oleh sistem seleksi masuk perguruan tinggi (PT) yang kurang sensitif gender, tetapi karena rendahnya partisipasi perempuan yang memilih jurusan IPA atau matematika di Madrasah Aliyah.

${ }^{1}$ Imam Tholkhah, "Kebijakan PUG dalam Penyelenggaraan Pendidikan Islam," Makalah disampaikan pada Temu Karya Pengarusutamaan Gender Bidang Pendidikan Islam, tidak dipublikasikan, Yogyakarta, 2009. 
Kedua, partisipasi perempuan dalam pembelajaran masih dipengaruhi stereotype gender terutama pada pelajaran keterampilan dan olah raga. Penulis buku ajar pada umumnya adalah laki-laki. Penulis perempuan yang memiliki sensitifitas gender masih minim. Akibatnya, pandangan dan cara pikir laki-laki masih mendominasi isi buku tersebut. Partisipasi orang tua siswa/siswi dalam mendukung kegiatan di sekolah masih menggunakan peran-peran yang stereotype gender.

Ketiga, pemegang keputusan di tingkat stakeholders pendidikan mayoritas laki-laki, misalnya Dinas Pendidikan, Dewan Pendidikan, Mapenda, DPRD. Penyusunan Rencana Pengembangan Sekolah (RPS) dan Rencana Anggaran Pendapatan dan Belanja Sekolah (RAPBS) masih didominasi laki-laki. Kepengurusan Komite Sekolah terutama peran pengambilan keputusan belum berkeseimbangan gender. Fungsi kontrol, akuntabilitas, dan evaluasi kinerja lainnya juga masih didominasi laki-laki. Keempat, sebagai akibat ketidaksamaan akses, partisipasi, dan kontrol antara laki-laki dan perempuan, manfaat yang diterima juga belum setara gender.

Pemegang jabatan struktural, akses, dan partisipasi dalam peningkatan kualitas guru melalui pelatihan dan workshop, kenaikan pangkat, lebih banyak laki-laki daripada perempuan karena adanya berbagai kendala budaya dan peran-peran gender yang tradisional. Pandangan masyarakat tentang peran gender yang dikotomis (produktif dan reproduktif) dan tidak adanya kebijakan pemenuhan kebutuhan gender praktis dan strategis, serta masih sulitnya peran gender tradisional dinegosiasikan berdampak pada beban ganda pada perempuan sehingga laki-laki lebih besar peluangnya memperoleh manfaat pendidikan. Hambatan di atas tentu saja berdampak pada kapasitas, profesionalisme, dan juga penghasilan yang tidak sama di antara keduanya.

Sebagai lembaga yang mengayomi penyelenggaraan pendidikan agama Islam, madrasah, dan pondok pesantren, Kementerian Agama (Kemenag) berupaya menjalin kemitraan dengan lembaga internasional untuk peningkatan kualitas dan pengembangan madrasah yang antara lain bermuatan PUG dalam pendidikan Islam. Meskipun demikian, belum ada akuntabilitas dan jaminan keberlanjutan program oleh Kemenag sendiri sehingga harus 
diakui secara obyektif bahwa kesenjangan gender masih (mungkin) terjadi di lembaga ini.

Pemikiran di atas setidaknya dilandasi oleh beberapa fakta, antara lain: Pertama, data EMIS tentang angka partisipasi sekolah siswi lebih rendah daripada siswa; Kedua, semakin tinggi jenjang pendidikan, semakin kecil jumlah partisipasi perempuan; Ketiga, jumlah guru perempuan dan lakilaki di Madrasah Ibtidaiyah sebenarnya seimbang, tetapi dalam pengajuan sertifikasi guru ternyata guru laki-laki lebih banyak lulus dibandingkan guru perempuan karena partisipasi guru perempuan lebih rendah dibandingkan guru laki-laki, baik dalam bidang karya tulis ilmiah maupun peningkatan jenjang karier; Keempat, sejumlah buku atau lembar kerja siswa/siswi masih memuat bias gender sebagai akibat pemahaman Islam secara tekstual yang terdapat dalam referensi guru sehingga berimplikasi pada pengembangan bahan ajar; dan Kelima, beberapa guru dan kepala madrasah masih banyak yang belum memiliki sensitivitas gender. ${ }^{2}$

Penelitian yang dilakukan oleh Ruminiati menemukan lima simpulan utama. Dua di antaranya yaitu: (1) tersubordinatnya karier guru perempuan berdampak pada rendahnya peluang guru perempuan untuk dipromosikan menjadi kepala sekolah dasar swasta. Hal ini merupakan dampak kebijakan aktor yayasan yang cenderung bias gender; dan (2) keyakinan aktor yayasan terhadap nilai agama yang ditafsirkan secara tekstual sehingga mereka berpandangan bahwa perempuan haram menjadi pemimpin. $^{3}$

Uraian singkat di atas menyiratkan bahwa implementasi PUG bidang pendidikan masih perlu dipertanyakan (kembali) karena kesetaraan gender sangat penting diperjuangkan demi terciptanya keadilan, kesejahteraan, dan keharmonisan laki-laki dan perempuan dalam kehidupan.

${ }^{2}$ Mufidah Ch, "Hasil Evaluasi Implementasi PUG Bidang Pendidikan Islam," Monev Pilot Project Pengarusutamaan Gender Bidang Pendidikan Islam di DI Yogyakarta, 5-6 Maret 2010, Dokumen tidak dipublikasikan. Program Kemitraan Kementerian Agama dengan MCPM-AIBEP

${ }^{3}$ Ruminiati, "Promosi Jabatan Kepala Sekolah Ditinjau dari Perspektif Gender: Penelitian Multi Situs di Berbagai Sekolah Dasar Swasta Bernuansa Agama dan Umum di Kota dan Kabupaten Malang Jawa Timur," Disertasi (Surabaya: PPS Universitas Airlangga, 2005), 326. 


\section{KONSEP GENDER BIDANG PENDIDIKAN ISLAM Pengertian Gender}

Istilah "gender" diartikan sebagai sifat atau karakter yang melekat pada dua jenis kelamin yang dikonstruksi secara sosial dan kultural. Lips ${ }^{4}$ memahami gender sebagai "cultural expectations for women and men," atau harapan-harapan budaya terhadap laki-laki dan perempuan. Sedangkan Margaret L. Andersen mendefiniskan gender sebagai berikut:

"Gender refers to the socially learned behaviors and expectations that are associated with two sexes. Thus, whereas 'maleness' and 'femaleness' are biological facts, masculinity and feminity are culturally constructed attributes. Similar to the social categories established by race and social class, gender patterns what others expect of us and what we expect of ourselves. Gender also establishes, in large measure, our life chances and directs our social relations with others."

Menurut Kantor Negara Kementerian Pemberdayaan Perempuan (KNPP), konsep gender:

“...mengacu kepada peran-peran yang dikonstruksikan dan dibebankan kepada perempuan dan laki-laki oleh masyarakat. Peran-peran ini dipelajari, berubah dari waktu ke waktu dan sangat bervariasi di dalam dan di antara berbagai budaya. Tidak seperti seks (perbedaan biologisantara perempuan dan laki-laki), gender mengacu kepada perilaku yang dipelajari dan harapan-harapan masyarakat yang membedakan antara maskulinitas dan femininitas." 5

Perbedaan jenis kelamin digunakan sebagai dasar pemberian peran sosial yang tidak sekedar menjadi pembeda dalam pembagian kerja, namun lebih dari itu juga menjadi instrumen pengakuan dan pengingkaran sosial, ekonomi, politik, serta penilaian peran dan hak-hak dasar laki-laki dan

${ }^{4}$ Hilary M. Lips, Sex \& Gender: An Introduction (London: Mayfield Publishing Company, 1993), 4.

${ }^{5}$ Portal.menegpp.go.id, (diakses Selasa, 26 Agustus 2008). 
perempuan, yang berimplikasi pada akses dan partisipasi keduanya termasuk dalam bidang pendidikan.

\section{Kebijakan Pengarusutamaan Gender dalam Pembangunan Nasional}

Keadilan dan kesetaraan gender adalah bagian dari penegakan prinsipprinsip universal dalam kehidupan. Ia merupakan amanat UUD 1945 dan komitmen nasional dalam penghapusan segala bentuk diskriminasi di Indonesia. Indonesia juga telah meratifikasi Convention on the Elimination of All Forms of Discrimination against Women (CEDAW) melalui UU No. 7 Tahun 1984 tentang Pengesahan Konvensi Penghapusan Segala Bentuk Diskriminasi terhadap Perempuan. ${ }^{6}$

Lahirnya Beijing Platform For Action (BPFA) tentang Gender Mainstreaming (Pengarusutamaan Gender) kesetaraan gender masuk dalam kebijakan pembangunan pada saat Konferensi Perempuan Dunia Keempat di Beijing tahun 1995, melalui kebijakan publik (governance) oleh pemerintah, swasta, organisasi sosial, dan pihak-pihak lain yang terkait. Sebagai bentuk komitmen pemerintah RI, Presiden Abdurrahman Wahid pada tanggal 19 Desember 2000 mengeluarkan Instruksi Presiden (Inpres) No. 9 Tahun 2000 tentang Pengarusutamaan Gender dalam Pembangunan Nasional. Tindak lanjut Inpres tersebut adalah penerbitan Surat Edaran Menteri Dalam Negeri dan Otonomi Daerah tanggal26 Juni 2001 No. 050/ 1232/SJ tentang Pelaksanaan Pengarusutamaan Gender dalam Pembangunan Nasional.Untukmendorong, mengefektifkan, danmengoptimalkan pelaksanaan pengarusutamaan gender secara terpadu dan koordinatif, Surat Edaran tersebut disempurnakan melalui Keputusan Menteri Dalam Negeri tanggal 29 Desember 2003 No. 132 Tahun 2003 tentang Pedoman Umum Pelaksanaan Pengarusutamaan Gender dalam Pembangunan di Daerah, yang kemudian dikuatkan oleh Peraturan Menteri Dalam Negeri No. 15 Tahun 2008 tentang Pedoman Pelaksanaan Pengarusutamaan Gender dalam Pembangunan Daerah, yang implementasinya dikoordinasi oleh Bappeda Provinsi dan Kabupaten/Kota.

${ }^{6}$ Tim Penyusun, Hak Azasi Perempuan: Instrumen Hukum untuk Mewujudkan Keadilan. (Jakarta: Yayasan Obor Indonesia, 2007), 8. 
Adapun tujuan pengarusutamaan gender (selanjutnya disingkat PUG) sebagaimana tercantum dalam lampiran Inpres No. 9 Tahun 2000 adalah terselenggaranya perencanaan, penyusunan, pelaksanaan, pemantauan, dan evaluasi atas kebijakan dan program pembangunan nasional berperspektif gender dalam kehidupan berkeluarga, bermasyarakat, berbangsa, dan bernegara. ${ }^{7}$ Implementasi PUG dapat membantu upaya identifikasi kesenjangan gender yang merupakan sumber permasalahan gender. Dengan demikian, tujuan akhir PUG adalah mempersempit atau bahkan meniadakan kesenjangan gender dalam seluruh aspek pembangunan. ${ }^{8}$

Implementasi Inpres No. 9/2000 di Indonesia telah membuahkan hasil antara lain: Pertama, meningkatnya program pembangunan di berbagai sektor; Kedua, meningkatnya anggaran responsif gender melalui Kementerian Pemberdayaan Perempuan dan Perlindungan Anak; Ketiga, meningkatnya dukungan anggaran lintas sektoral untuk kesetaraan gender; Keempat, menguatnya kelompok-kelompok penggerak dalam koordinasi pelaksanaan PUG; Kelima, lahirnya sejumlah undang-undang yang memberikan perlindungan pada perempuan dan anak untuk menghapus diskriminasi gender. ${ }^{9}$

\section{Kebijakan Pengarusutamaan Gender Bidang Pendidikan}

Dalam konteks pendidikan, PBB telah menyelenggarakan Pertemuan Millenium di New York pada September 2000. Pertemuan yang dihadiri 189 negara anggota PBB tersebut menyepakati 'Delapan Tujuan Pembangunan Millenium' atau Millenium Development Goals (MDGs) yang salah satu hasilnya adalah pencanangan 'Pendidikan untuk Semua' atau Education for All (EFA) pada Konferensi Internasional di Dakkar, yaitu: (1) memberlakukan pendidikan dasar yang universal, memastikan bahwa anak laki-laki dan perempuan dapat menyelesaikan pendidikan dasar (pada poin 2); dan (2) mengembangkan kesetaraan dan

${ }^{7}$ Tim Penyusun, Panduan Pelaksanaan Inpres Nomor 9 Tahun 2000 tentang Pengarusutamaan Gender dalam Pembangunan Nasional (Jakarta: Kementerian Pemberdayaan Perempuan, 2002), 53.

${ }^{8}$ Ibid., 3.

${ }^{9}$ Mufidah Ch, Bingkai Sosial Gender: Islam, Strukturasi, dan Konstruksi Sosial (Malang: UIN Maliki Press, 2009), 107-108. 
pemberdayaan perempuan, menghilangkan perbedaan gender di tingkat pendidikan dasar, menengah, serta di semua tingkatan (pada poin 3). ${ }^{10}$

Implementasi PUG dalam pendidikan nasional dikuatkan oleh Peraturan Menteri Pendidikan Nasional No. 84 Tahun 2008 tentang Pedoman Pelaksanaan Pengarusutamaan Gender Bidang Pendidikan. Regulasi ini menjadi landasan PUG bidang pendidikan, termasuk pada lembaga pendidikan Islam, baik negeri maupun swasta, dan pada semua satuan pendidikan mulai Pendidikan Anak Usia Dini (PAUD) hingga jenjang Perguruan Tinggi.

Respon progresif Kementerian Pendidikan Nasional (Kemendiknas) terhadap PUG juga tampak dalam enam Renstra Kemendiknas Tahun 2010-2014 yang secara eksplisit memuat kesetaraan gender, yaitu: Pertama, perluasan dan pemerataan akses Pendidikan Anak Usia Dini (PAUD) bermutu dan berkesetaraan gender; Kedua, perluasan dan pemerataan akses pendidikan dasar universal bermutu dan berkesetaraan gender; Ketiga, perluasan dan pemerataan akses pendidikan menengah bermutu, berkesetaraan gender, dan relevan dengan kebutuhan masyarakat; Keempat, perluasan dan pemerataan akses pendidikan tinggi bermutu, berdaya saing internasional, berkesetaraan gender, dan relevan dengan kebutuhan bangsa dan negara; Kelima, perluasan dan pemerataan akses pendidikan orang dewasa berkelanjutan yang berkesetaraan gender dan relevan dengan kebutuhan masyarakat; Keenam, penguatan tata kelola, sistem pengendalian manajemen, dan sistem pengawasan intern. ${ }^{11}$

Selanjutnya, Kemendiknas memiliki sejumlah model implementasi PUG bidang pendidikan di tingkat Kabupaten/Kota, antara lain di Kabupaten Kebumen, Jawa Tengah. Permendiknas No. 84 Tahun 2008 cukup efektif dalam mendorong terwujudnya kesetaraan dan keadilan gender bidang pendidikan. Beberapa faktor yang berpengaruh terhadap efektivitas implementasi Permendiknas tersebut adalah adanya komitmen politik dari policy maker, berfungsinya kelompok kerja PUG dan gender focal point di unit kerja maupun satuan pendidikan, adanya sensitivitas gender

${ }^{10}$ Tim Penyusun, Panduan Pengarusutamaan Gender Bidang Pendidikan: Buku II Kebijakan Pengarusutamaan Gender Bidang Pendidikan (Malang: Indonesia Australia Partnership In Basic Education, 2007), 1 April 2011.

11 "Rencana Strategis Diknas 2010-2014," http/www.diknas.go.id, diakses 5 
stakeholder pendidikan, tersedianya sistem dan informasi data terpilah menurut jenis kelamin, adanya dukungan anggaran untuk pelaksanaan PUG pendidikan, serta adanya bimbingan teknis PUG pendidikan dari pemerintah tingkat Provinsi. ${ }^{12}$

\section{PENDIDIKAN ISLAM BERPERSPEKTIF GENDER}

Salah satu hak dasar individu baik laki-laki maupun perempuan adalah mendapatkan pendidikan yang setara. Pendidikan menjadi sangat penting karena dengan pendidikanlah manusia dapat berpengetahuan, bermartabat, dan pada akhirnya mencapai hidup sejahtera di tengahtengah masyarakat. Konsep pendidikan dalam Islam dikaitkan dengan istilah tarbiyah, ta 'lim, dan ta'dib. Ketiganya memiliki makna mendalam yang menyangkut manusia, masyarakat, dan lingkungan dalam hubungannya dengan Tuhan. Hasan Langgulung merumuskan pendidikan Islam sebagai suatu proses penyiapan generasi muda untuk mengisi peranan, pemindahan pengetahuan, dan nilai-nilai Islam yang diselaraskan dengan fungsi manusia untuk beramal di dunia dan memetik hasilnya di akhirat. ${ }^{13}$

Fakta di lapangan menunjukkan bahwa tidak semua warga negara bisa mengakses pendidikan yang layak. Masalah bias gender di kalangan masyarakat ternyata menjadi salah satu penyebab beberapa anak bangsa tidak mendapatkan hak pendidikan. Padahal ajaran Islam menyebutkan bahwa tidak ada perlakuan diskriminatif bagi setiap individu baik laki-laki maupun perempuan di muka bumi ini yang didasarkan pada perbedaan jenis kelamin, status sosial, ataupun ras. Semua manusia memiliki kedudukan yang sama di sisi Allah. Allah membedakan kedudukan manusia di sisi-Nya berdasarkan kualitas ketakwaannya. ${ }^{14}$

Pendidikan Islam berperspektif gender hadir untuk memberikan dan menjamin terpenuhinya hak pendidikan yang sama bagi laki-laki dan perempuan. Ia merupakan proses transformasi pengetahuan dan nilai-nilai

${ }^{12}$ Ismi Dwi Astuti Nurhaeni, "Efektifitas Regulasi Permendiknas No. 84 Tahun 2008 tentang Pengarusutamaan Gender Bidang Pendidikan (Studi Kasus di Kab. Kebumen)", Yustisia, 78, (Surakarta, September-Desember, 2009), 43.

${ }^{13}$ Hasan Langgulung, Beberapa Pemikiran tentang Pendidikan Islam (Bandung: Al-Ma'arif, 1979), 6.

${ }^{14}$ Tim Penyusun, Membangun Relasi Setara antara Perempuan dan Lakilaki Melalui Pendidikan Islam (Jakarta: Direktoral Jenderal Pendidikan Kementerian Agama-Australia Indonesia Partnership, 2010), 33-34 
Islam berlandaskan al-Qur'an dan Hadis Nabi untuk mengantarkan terbentuknya kepribadian Islami dengan mempertimbangkan perbedaan kebutuhan, pengalaman, dan pengetahuan laki-laki dan perempuan akibat konstruksi sosial lingkungannya, menuju pendidikan berkesetaraan gender agar keduanya memperoleh manfaat yang sama dari hasil pendidikan dalam mencapai tujuan yang diharapkan.

\section{Tujuan Pendidikan Islam Berperspektif Gender}

Tujuan pendidikan Islam tidak lepas dari tujuan hidup Muslim, yaitu menciptakan pribadi-pribadi bertakwa yang dapat mencapai kebahagiaan hidup di dunia dan akhirat. Idealisme ini seringkali disebut sebagai tujuan akhir pendidikan Islam. Pendidikan Islam diharapkan mampu merealisasikan tujuan hidup manusia sebagaimana digariskan dalam ajaran Islam, yaitu beribadah kepada Allah. ${ }^{15}$ Tujuan mulia pendidikan Islam tersebut sama sekali bebas dari bias gender akibat perbedaan jenis kelamin. Sayangnya, implementasi ajaran Islam yang sebenarnya tidak mendiskriminasi pendidikan bagi laki-laki dan perempuan dalam kehidupan sehari-hari masih patut dipertanyakan. Adapun tujuan khusus pendidikan Islam responsif gender dirumuskan secara spesifik berupa harapan-harapan yang ingin dicapai dalam proses pendidikan. Hasil pendidikan tersebut selanjutnya dinilai berdasarkan capaian terhadap indikator yang telah dirumuskan sebelumnya dengan mempertimbangkan kesetaraan gender pada akses, partisipasi, kontrol atas sumber daya pendidikan Islam, dan manfaat dari hasil pendidikan Islam.

\section{Dasar-Dasar Pendidikan Islam Berperspektif Gender}

Konsep pendidikan Islam secara umum bersumber dari al-Qur' an dan al-Sunnah, nilai-nilai sosial kemasyarakatan, dan wawasan pemikiran Islam. ${ }^{16}$ Dengan demikian pendidikan Islam berperspektif gender diimplementasikan berdasarkan pada: Pertama, ajaran al-Qur' an dan alSunnah yang meliputi penghargaan Islam terhadap akal, keutamaan dan kewajiban menuntut ilmu, serta nilai-nilai kesetaraan dan keadilan gender;

${ }^{15}$ Ahmad Tafsir, Ilmu Pendidikan dalam Perspektif Islam (Bandung: PT Remaja Rosdakarya, 2005), 46.

${ }^{16}$ Hasan Langgulung, Beberapa Pemikiran tentang Pendidikan Islam (Bandung: Al-Ma'arif, 1979), 7. 
Kedua, nilai-nilai sosial kemasyarakatan yang selaras atau tidak bertentangan dengan ajaran Islam atas dasar manfaat, dan menghindari kendala-kendala yang dihadapi oleh laki-laki maupun perempuan, sehingga kedua jenis kelamin sama-sama memperoleh hasil belajar yang baik; Ketiga, warisan pemikiran Islam yang berpotensi mendorong terwujudnya kesetaraan gender sebagai bahan pengembangan pendidikan Islam yang bermuara pada prinsip dasar Islam sebagai agama yang ramah terhadap perbedaan gender dan perbedaan-perbedaan lainnya.

\section{Prinsip-Prinsip Pendidikan Islam Berperspektif Gender}

Prinsip-prinsip pendidikan Islam menurut Hasan Langulung pada dasarnya tidak jauh berbeda dengan prinsip-prinsip pendidikan padaumumnya, antara lain: Pertama, pendidikan berusaha menumbuhkembangkan seluruh potensi individu dalam mempersiapkan kehidupan yang mulia di tengah-tengah masyarakat; Kedua, pendidikan merupakan proses dinamis dan berkesinambungan yang meliputi semua aspek kehidupan secara individu maupun kolektif di masyarakat; Ketiga, pendidikan dalam pengertian menyeluruh bertemu dan berjalin dengan konsep-konsep dan proses belajar, pertumbuhan, interaksi, penyerapan pengalaman, adaptasi, kondisi psikologis, dan perubahan sosial yang dapat mengubah tingkah laku individu dan kehidupan masyarakat; Keempat, pendidikan mengantarkan manusia menuju keutuhan dan kesempurnaan secara berproses dalam semua aspek (intelektual, spiritual, emosional, dan sosial) untuk kehidupan dunia dan akhirat. ${ }^{17}$

Menurut Mursi, ${ }^{18}$ pendidikan Islam harus memenuhi beberapa prinsip, antara lain: Pertama, menyeluruh, yaitu meliputi segala aspek kehidupan manusia baik jasmani maupun rohani; Kedua, berfokus pada keseimbangan dunia dan akhirat; Ketiga, bersifat teoritis dan praktis; Keempat, bersifat personal dan sosial; Kelima, tidak menyalahi fitrahnya sebagai makhluk yang baik.

${ }^{17}$ Hasan Langgulung, Azas-azas Pendidikan Islam (Jakarta: Pustaka AlHusna, 1988), 60-62.

${ }^{18}$ Anonim, "Prinsip-prinsip Pendidikan Islam," http://sutisna.com/artikel/ artikel-kependidikan. (Diakses, 28 April 2011). 
Uraian di atas, ada lima prinsip utama pendidikan Islam berperspektif gender, yaitu prinsip integrasi, keseimbangan, persamaan, pendidikan seumur hidup, dan idealisme. ${ }^{19}$ Lebih jelasnya dapat dijelaskan sebagai berikut:

Prinsip integrasi; Pendidikan Islam senantiasa mengembangkan segala potensi dan bakat manusia tanpa dibatasi oleh jenis kelamin. Potensi manusia bervariasi dan berjenjang, namun Islam tidak mengindikasikan sedikit pun bahwa keunggulan potensi ditentukan oleh jenis kelamin. Prinsip keseimbangan; Pendidikan Islam mengambil jalan tengah antara kepentingan hidup dunia dan akhirat, kebutuhan jasmani dan rohani, materiil dan spiritual, dan antara kebutuhan gender (praktis maupun strategis) lakilaki dan perempuan yang merupakan modal untuk memahami makna dan tujuan hidup berkeseimbangan sebagaimana prinsip Islam itu sendiri. Prinsip persamaan; Al-Qur' an surat al-Ḥjurāt, 49:13 menegaskan bahwa manusia pada dasarnya memiliki kesamaan derajat di hadapan Allah dalam memperoleh hak-hak dasar dan tanggung jawabnya sebagai manusia tanpa membedakan suku, etnis, dan jenis kelamin. Prinsip pendidikan seumur hidup; Pendidikan yang ditanamkan kepada manusia dalam konsep Islam tanpa batas usia. Oleh sebab itu, Islam mendorong setiap manusia, lakilaki maupun perempuan, untuk terus belajar sepanjang usia. Pembatasan usia belajar yang dialamatkan kepada jenis kelamin tertentu sesungguhnya bertentangan dengan prinsip pendidikan Islam ini. Prinsip idealism; Pendidikan Islam mengantarkan manusia untuk mencapai nilai-nilai Islam yang ideal yakni insan paripurna yang memiliki moral tauhid. Pendidikan Islam tidak sekedar mengantarkan manusia untuk menjalani proses belajar sesuai dengan target-target penguasaan materi yang bersifat formalistik dan mekanik, tetapi lebih pada pembentukan kepribadian melalui keteladanan dan perlakuan baik tanpa diskriminasi gender, sebab kepribadian paripurna tidak ditentukan oleh jenis kelamin, melainkan oleh ikhtiar setiap manusia, baik laki-laki maupun perempuan.

\section{Metode Pendidikan Islam Berperspektif Gender}

Dalam beberapa literatur, metode yang digunakan dalam pendidikan Islam meliputi: Pertama, metode rasional (manhaj 'aqlī); Kedua, metode intuitif

${ }^{19}$ Tim Penyusun, Membangun Relasi Setara, 35-36. 
(manhaj dhawqi) ; Ketiga, metode dialogis (manhaj jadalī); Keempat, metode komparatif (manhaj muqāranī); dan Kelima, metode kritik (manhaj naqdi). ${ }^{20}$

Penggunaan metode rasional (manhaj 'aqlī) dalam pendidikan Islam berlandaskan pada keyakinan bahwa umat Muslim dituntut berpikir rasional, yaitu mendayagunakan akal secara maksimal untuk memahami kebenaran al-Qur' an dan al-Sunnah dengan baik. Dalam perspektif gender, metode rasional (manhaj 'aqlī) digunakan untuk memahami Islam sebagai agama yang ramah terhadap laki-laki maupun perempuan, menjujunjung tinggi martabat manusia bukan atas dasar jenis kelamin, melainkan atas dasar ketakwaan. Metode ini juga digunakan untuk menganalisis realitas kesenjangan gender yang terjadi akibat kurangnya pemahaman nilai-nilai universal Islam sesuai dengan kemampuan nalar. Apabila nilai-nilai universal tersebut dapat dipahami dengan baik, setiap anak laki-laki dan perempuan akan mampu belajar secara kompetitif dan kooperatif agar bisa mandiri dan bertanggung jawab.

Metode intuitif (manhaj dhawqī) sangat mungkin digunakan karena setiap manusia memiliki kecakapan (meski cukup beragam) untuk memperoleh pengetahuan. Di kalangan filosof Muslim, misalnya, intuisi digunakan untuk mendukung kinerja filsafat yang mereka tekuni. ${ }^{21}$ Dalam konteks pendidikan Islam berperspektif gender, metode ini dapat membangun sensitivitas gender seseorang sebab pengetahuan tentang gender dalam perspektif Islam belum cukup menjamin seseorang memiliki keajegan (ke-istiqämah-an) dalam memegang komitmen kesetaraan dan keadilan gender. Melalui metode intuitif seseorang mampu menguak tabir misteri dan menjawab pertanyaan mendasar, antara lain: Mengapa laki-laki dan perempuan dalam hal status, peran, dan tanggung jawab masih dibedakan?; Mengapa kesenjangan dan diskriminasi gender sering terjadi dalam kehidupan?; Ketiga, Mengapa kesetaraan gender penting dalam mewujudkan kehidupan yang harmonis? Pertanyaan-pertanyaan kritis di

\footnotetext{
${ }^{20}$ Mujamil Qomar, Epistimologi Pendidikan Islam: Dari Metode Rasional Hing ga Metode Kritik (Jakarta: Erlangga, 2005), 270-350.

${ }^{21}$ Irfan Achmad Khan, "Elemen-Elemen Empiris, Intuitif, dan Rasional Terjalin dalam Pengetahuan Kita: The Islamic Method" dalam Muhammad Muqim (ed.), Research Methodology in Islamic Perspective (New Delhi: Institute of Objective Studies, 1994), 68.
} 
atas dapat dijawab melalui metode intuitif seperti tafakur, kontemplasi, introspeksi, dan sejenisnya agar sensitivitas gender seseorang semakin terasah.

Sementara itu, metode dialogis (manhajjadalī), yaitu upaya menggali pengetahuan pendidikan Islam melalui proses tanya jawab, dapat menumbuhkan sikap keterbukaan: saling memberi dan menerima. Metode dialogis dalam pendidikan Islam diharapkan mampu menjembatani kesenjangan perspektif, keyakinan, dan perbedaan pengalaman antara lakilaki dan perempuan akibat konstruksi sosial masyarakat. Dengan metode ini pula, laki-laki dan perempuan dapat berkomunikasi dan berinteraksi dengan saling memahami, menghargai, dan bekerjasama untuk kebaikan berdasarkan nilai-nilai Islam yang sebenarnya menghargai hak-hak dasar manusia baik laki-laki maupun perempuan sebagai makhluk bermartabat.

Metode komparatif (manhaj muqārani) dapat digunakan untuk membandingkan konsep dan penerapan pendidikan Islam dengan pendidikan (model) lain. Komparasi yang meliputi dasar, tujuan, metode, dan materi pendidikan ini diharapkan dapat menghasilkan inovasi pengetahuan keislaman dan memunculkan ide-ide progresif pendidikan Islam yang sejalan dengan kondisi dan kebutuhan masyarakat serta kemajuan ilmu pengetahuan dan teknologi. Dalam konteks pendidikan Islam yang berkesetaraan gender metode komparatif digunakan untuk membandingkan konsep dan implementasi pendidikan Islam yang netral gender, bias gender, dan responsif gender. Perbandingan ini diharapkan dapat mendorong perubahan pada pendidikan yang masih netral gender dan bias gender menuju pendidikan responsif gender.

Sedangkan metode kritik (manhaj naqdī) dimaksudkan sebagai usaha menggali pengetahuan tentang pendidikan Islam dengan cara mengoreksi kelemahan-kelemahan konsep dan implementasi pendidikan Islam yang telah lalu dan yang sedang berlangsung, kemudian menawarkan solusi alternatifnya. Kritik berperan penting dalam mewujudkan dinamika ilmu pengetahuan, juga menjadi motif utama dalam semangat gerakan intelektual dalam pengembangan pendidikan Islam. Pada dasarnya konsep pendidikan Islam yang bersumber dari nilai-nilai al-Qur' an dan al-Sunnah tidak mengindikasikan diskriminasi terhadap jenis kelamin tertentu, namun ditemukan sejumlah penerapan pendidikan Islam yang bias gender akibat 
penafsiran teks yang cenderung ahistoris, penggunaan metode penafsiran yang kurang tepat, dan infiltrasi budaya patriarkhi. Akibatnya, akses dan partisipasi perempuan lebih rendah dibandingkan laki-laki. Metode kritik digunakan untuk menelaah kembali penyebab kesenjangan gender pada pendidikan Islam dan menemukan solusi yang tepat dalam perspektif Islam agar laki-laki maupun perempuan, menjadi sebaik-baik umat.

\section{Pentingnya Pendidikan Islam Berperspektif Gender}

Pendidikan Islam berkesetaraan gender menjadi bagian dari inovasi pemikiran Islam tentang pendidikan yang memuat berbagai manfaat bagi generasi ke depan dalam membangun kehidupan umat yang lebih harmonis, antara lain untuk: pertama, mengatasi masalah kesenjangan gender dalam pendidikan Islam di masyarakat sebagai dampak konstruksi sosial yang cenderung masih bias gender; kedua, menghilangkan diskriminasi dalam perencanaan, pelaksanaan, dan pemantauan pendidikan; ketiga, membangun kesadaran gender terhadap pelaku pendidikan, manajemen, pembelajaran, dan budaya pendidikan yang ramah gender; keempat, mewujudkan masyarakat yang egaliter, menghormati hak-hak dasar manusia dan menciptakan relasi harmonis dalam kehidupan berlandaskan nilai-nilai Islam.

\section{SUDAHKAH KESETARAAN GENDER MENJADI ARUS UTAMA PENDIDIKAN ISLAM?}

Kesetaraan dan keadilan gender dalam pendidikan Islam merupakan konsep besar yang bersifat universal. Upaya mewujudkan kesetaraan dan keadilan gender tersebut membutuhkan strategi implementasi khususnya pada lingkup pendidikan Islam melalui PUG bidang pendidikan Islam. PUG bidang pendidikan Islam adalah suatu pendekatan untuk mengembangkan kebijakan pembangunan yang mengintegrasikan pengalaman dan masalah perempuan dan laki-laki dalam proses perencanaan, pelaksanaan, pemantauan, dan evaluasi kebijakan dan program pendidikan Islam di tingkat nasional, daerah, dan setiap satuan pendidikan Islam guna mencapai kesetaraan dan keadilan gender. 
Integrasi kesetaraan gender dalam bidang pendidikan Islam dapat dilakukan melalui:pertama, kebijakan PUG bidang pendidikan Islam; kedua, manajemen dan budaya di tingkat satuan pendidikan Islam; ketiga, kurikulum dan pembelajaran pendidikan Islam di dalam kelas; keempat, peran serta masyarakat dan komite madrasah; kelima, sinergi pendidikan Islam dengan pendidikan di bawah naungan Kemendiknas.

Implementasi PUG bidang pendidikan Islam sangat ditentukan oleh kebijakan PUG yang mengacu pada terpenuhinya unsur-unsur atau yang lazim disebut komponen kunci $^{22}$ sebagai berikut:

\section{Komitmen Politik}

Kesepakatan di tingkat pengambil kebijakan baik eksekutif maupun legislatif menjadi modal awal untuk bersama-sama melaksanakan Inpres No. 9 Tahun 2000 tentang PUG. Komitmen politik ini penting karena menyangkut persoalan penyusunan rencana strategis, khususnya peraturan yang menyangkut pendidikan dan penganggaran pendidikan Islam responsif gender. Landasan yuridis untuk melaksanakan PUG bidang pendidikan Islam belum ditetapkan melalui Peraturan Menteri (Agama) sebagaimana yang telah dilakukan oleh Kemendiknas sehingga kerangka kebijakan belum mampu mengatur pelaksanaan PUG di bidang pendidikan Islam. Renstra yang disusun di bidang pendidikan Islam juga belum memberikan porsi khusus sebagai upaya akselerasi PUG bidang pendidikan Islam melalui Kemenag.

Komitmen politik ini juga terkait dengan mindset pengambil keputusan (decision maker) yang berpengaruh pada political will. Jika para pengambil kebijakan memiliki sensitivitas gender, kebijakan yang dikeluarkan juga akan responsif gender. Pun demikian sebaliknya: kurangnya sensitivitas gender dapat memicu dan memantik munculnya kebijakan bias gender sehingga mengabaikan dan membiarkan ada/tidak adanya kesenjangan gender yang terjadi atau memandang gender bukan sebagai masalah struktural maupun kultural.

${ }^{22}$ Panduan Pelaksanaan Inpres Nomor 9Tahun 2000 tentang Pengarusutamaan Gender dalam Pembangunan Nasional, 2002. 


\section{Kelembagaan/Struktur}

Kepmendagri No. 15/2008 yang menghendaki agar setiap Satuan Kerja membentuk Pokja (kelompok kerja) PUG tingkat nasional dan daerah ternyata tidak berlaku efektif. Walaupun Pokja PUG di tingkat Kemenag RI dan Kanwil Kemenag telah dibentuk, keduanya belum berjalan secara efektif. Program kegiatan yang tercantum dalam Renstra Kemenag untuk mendukung kesetaraan gender hanya terdapat dalam sub kegiatan. Upaya mengintegrasikan kesetaraan gender dalam berbagai kegiatan yang memungkinkan juga belum memiliki perangkat yang memadai. PUG sekadar dimasukkan dalam kluster penelitian dan pertimbangan penentuan penerima bantuan dana penelitian dan pengabdian masyarakat pada Direktorat Pendidikan Tinggi Islam. Apalagi, karena kebijakan ini hanya dijamin secara personal atau kelompok, bukan melalui peraturan institusional yang mengikat, perubahan kebijakan dapat terjadi sewaktu-waktu.

\section{Sumber Daya}

Tersedianya SDM yang memiliki komitmen tinggi dan sensitifitas gender merupakan kunci keberhasilan PUG. SDM merupakan unsur penting sebagai motivator, fasilitator, dan negosiator yang menggerakkan PUG bidang pendidikan yang disebut dengan gender focal point (GFP) ${ }^{23}$ Dalam dunia pendidikan Islam, pejabat pengambil kebijakan, pimpinan lembaga/ yayasan pendidikan Islam, kepala madrasah, guru, dan pengasuh sangat menentukan perubahan kondisi pendidikan Islam yang masih memiliki problem ketimpangan gender baik dalam ranah kebijakan, manajemen, maupun pembelajaran.

Sejumlah kasus kesenjangan gender di lembaga pendidikan Islam sangat sulit untuk dibongkar kecuali dengan keterlibatan GFP sebagai pelaku kunci dalam melakukan perubahan dan berada pada posisi terdepan. Harapan ini bukan hal yang mustahil. Hasil penelitian di Pesantren Salafiyah Syafi'iyah Sukorejo, Situbondo, Jawa Timur menunjukkan bahwa implementasi PUG dapat berhasil baik karena adanya dukungan dan peran

${ }^{23}$ Aparatur yang memiliki kemampuan untuk melaksanakan pengarusutamaan gender pada SKPD. Lihat: Permendagri No. 15/2008. Bisa juga individu-individu stakeholder yang memiliki tanggung jawab terhadap kesetaraan gender. 
GFP, khususnya SDM perempuan berkualitas, yang memiliki sensitivitas dan responsibilitas gender. ${ }^{24}$

\section{Sistem Informasi dan Data}

Istilah gender masih dianggap asing, tabu, bahkan berbahaya. Konsep gender relatif masih belum dipahami dengan baik oleh masyarakat tidak terkecuali masyarakat dalam lingkup lembaga pendidikan Islam. Implementasi PUG memerlukan adanya sistem informasi yang memuat data terpilah laki-laki dan perempuan. Informasi dan data ini bermanfaat untuk menemukenali kesenjangan gender di lembaga pendidikan Islam sebagai pembuka wawasan. Data gender dapat berbentuk kuantitatif dan kualitatif. Keduanya sangat penting sebagai entri point kebijakan, manajemen, kurikulum, dan implementasi pembelajaran di dalam kelas. Validitas data kuantitatif maupun kualitatif yang tersedia akan menentukan ketepatan dan akselerasi implementasi PUG. Dalam realitasnya, data EMIS yang tersedia di Kemenag belum digunakan secara maksimal untuk mendukung kebijakan responsif gender pada pendidikan Islam. Sejumlah temuan hasil penelitian tentang kesenjangan gender bidang pendidikan Islam juga tidak dimanfaatkan untuk mengubah kondisi yang ada.

\section{Alat Analisis dan Gender Analysis Skill}

Metode yang diperlukan untuk membantu implementasi PUG bidang pendidikan Islam mencakup gender analysis pathway (GAP) dan problem-based approach (PROBA) berdasarkan data kualitatif maupun kuantitatif tentang pendidikan Islam dan data terpilah berdasarkan jenis kelamin. Adapun gender analysis skill merupakan keterampilan dalam menggunakan alat analisis PUG sebagai strategi menuju kesetaraan gender bidang pendidikan Islam. Keterampilan dalam menganalisis kesenjangan gender ini ditopang pula oleh sensitivitas gender SDM. Alat analisis gender untuk menemuken kesenjangan gender yang terjadi pada kebijakan, manajemen, dan pembelajaran pendidikan Islam belum digunakan secara maksimal. Ketersediaan SDM yang memiliki keterampilan analisis gender

${ }^{24}$ Mufidah Ch, Gender di Pesantren Salaf, Why Not?Menelusuri Jejak Konstruksi Sosial Pengarusutamaan Gender di Kalangan Elit Santri (Malang: UIN Maliki Malang Pr 
di perguruan tinggi Islam seperti PSW/PSG sebenarnya bisa memberikan kontribusi dalam bentuk penelitian dan kajian-kajian, namun Kemenag belum memaksimalkan peran perguruan tinggi Islamuntuk mendukung implementasi PUG ini.

\section{Alat dan Sistem Monitoring dan Evaluasi}

Salah satu unsur dalam implementasi PUG adalah sistem evaluasi. Pengukuran tingkat keberhasilan pelaksanaan PUG bidang pendidikan Islam dapat dilakukan secara integratif dengan instrumen penilaian yang tersedia. Bentuk evaluasi penerapan PUG bidang pendidikan ini antara lain: pertama, impact study dengan menghadirkan GFP atau stakeholders PUG bidang pendidikan Islam untuk mengidentifikasi dan menganalisis indikator capaian PUG melalui focused group discussion (FGD) implementasi PUG bidang pendidikan Islam; kedua, melihat perubahan yang terjadi melalui bukti-bukti fisik seperti adanya Renstra Kemenag, program kegiatan, Renstra satuan pendidikan Islam (madrasah), struktur organisasi madrasah, kurikulum tingkat madrasah, rencana pelaksanaan pembelajaran (RPP), karya tulis perspektif gender, dan penggunaan media KIE; ketiga, perubahan komposisi siswa maupun siswi dari aspek jumlah, partisipasi dalam kegiatan madrasah, komposisi guru laki-laki dan perempuan dari aspek jenjang karier, partisipasi dalam pengambilan keputusan, dan sebagainya; keempat, survei/penelitian yang dilakukan dengan menghadiri kegiatan-kegiatan rutin dimana PUG bidang pendidikan Islam telah diterapkan. Terkait dengan data, alat analisis, dan gender analysis skill, sejumlah alat dan sistem monitoring/evaluasi sebagaimana uraian dimaksud ternyata belum dapat diterapkan sebagai bagian dari sistem evaluasi kebijakan, manajemen, dan pembelajaran pendidikan Islam responsif gender.

\section{Komunikasi, Informasi, dan Edukasi (KIE)}

Upaya menumbuhkan dan meningkatkan kemampuan instansi dan lembaga pemerintah di tingkat pusat dan daerah dalam mengimplementasikan PUG bidang pendidikan Islam antara lain melalui KIE. Bentuk-bentuk KIE yang dipandang efektif untuk implementasi PUG bidang pendidikan Islam antara lain: pertama, forum ilmiah seperti seminar, workshop, pelatihan, studi 
banding, dan sebagainya; kedua, forum yang dilengkapi dengan media KIE, misalnya sosialisasi kesetaraan gender dalam pertemuan-pertemuan stakeholder pendidikan Islam dalam Kelompok Kerja Madrasah (KKM), Musyawarah Guru Mata Pelajaran (MGMP), Kelompok Kerja Guru (KKG), Komite Madrasah, Paguyuban Kelas, dan sejenisnya; ketiga, media cetak seperti publikasi karya ilmiah atau hasil penelitian, buletin, buku saku, leaflet, buklet, komik, koran, stiker, dan media sejenis yang memuat pesan-pesan kesetaraan gender; keempat, benda-benda yang memuat pesan kesetaraan gender dan pendidikan Islam dalam bentuk tulisan, jargon, maupun simbol-simbol yang mudah dilihat, dipahami, dan mengesankan, seperti hiasan dinding, pajangan, vas bunga, lukisan, gambar, poster; kelima, pesan-pesan kesetaraan gender dan pendidikan Islam yang ditempatkan pada benda-benda yang biasa disentuh dan digunakan setiap hari seperti tempat HP, kipas, gantungan kunci, pembatas buku, cangkir, alat-alat tulis; Keenam, audio atau audio-visual seperti film pendidikan Islam berwawasan gender dalam bentuk $\mathrm{CD}$, kaset, atau sejenisnya; ketujuh, dialog/perbincangan, maupun iklan layanan masyarakat yang bertema kesetaraan gender dalam pendidikan Islam melalui radio dan televisi; kedelapan, permainan out-bond/in-bond, simulasi, drama, nyanyian, kasidah, dan kegiatan lain yang sejenis.

Dari sejumah alternatif media KIE tersebut, sebagian telah disediakan oleh beberapa lembaga/organisasi/project yang mewajibkan gender terintegrasi dalam kegiatan. Namun demikian, secara spesifik Kemenag belum menjadikan isu kesetaraan gender sebagai gerakan masif untuk mendukung akselerasi kesetaraan gender di bidang pendidikan Islam sebagaimana yang dilakukan oleh Kemendiknas.

\section{Dukungan Masyarakat}

PUG tidak dapat dilaksanakan tanpa dukungan masyarakat. Dalam konteks ini sebagai subyek yang aktif sekaligus menjadi bagian dari sistem PUG bidang pendidikan Islam. Perubahan sistemik akan terwujud dengan kehadiran dan peran masyarakat dalam melakukan upaya-upaya secara sinergis dengan berbagai unsur masyarakat yang ada. Implementasi PUG bidang pendidikan Islam bukan berarti bersifat eksklusif melainkan inklusif, sebab pendidikan Islam merupakan salah satu instrumen strategis untuk 
mengubah bias gender menjadi responsif gender, untuk mewujudkan masyarakat yang berkesetaraan dan keadilan gender. Sinergitas lembagalembaga pendidikan Islam dengan berbagai pihak menjadi kunci keberhasilan PUG bidang pendidikan Islam. Strategi memotivasi masyarakat agar proaktif adalah melalui peran tokoh agama, tokoh masyarakat, dan stakeholder lainnya sebagai GFP. Sosialisasi PUG bidang pendidikan Islam di tengah-tengah masyarakat juga memerlukan dukungan media KIE yang sesuai.

Hingga kini, masih ditemui sejumlah kendala yang menghambat partisipasi masyarakat dalam mendukung implementasi PUG yang disebabkan oleh: pertama, pro-kontra terhadap gender sebagai istilah konseptual, di mana istilah "gender" masih dicurigai dan distigma negatif; kedua, budaya patriarkhi yang menjadikan laki-laki lebih unggul; ketiga, penafsiran agama yang bias gender; keempat, landasan yuridis dan tersedianya strategi pelaksanaannya belum menjamin para pengambil kebijakan memiliki sensitivitas gender dan political will terhadap implementasi PUG itu sendiri.

\section{PENUTUP}

Negara telah memiliki landasan yuridis untuk melaksanakan PUG dalam pembangunan melalui Inpres No. 9/2000 yang berfungsi sebagai dukungan pelaksanaan "pendidikan untuk semua" yang menjadi komitmen internasional. Meskipun demikian, implementasi PUG di bidang pendidikan Islam masih belum memenuhi harapan. Hal ini disebabkan oleh:pertama, komitmen dan political will terhadap isu-isu gender bidang pendidikan Islam masih rendah, sehingga implementasi PUG dalam bentuk kebijakan, manajemen, dan pembelajaran bidang pendidikan Islam belum maksimal; kedua, sejumlah data kesenjangan gender belum ditindaklanjuti melalui analisis gender; ketiga, SDM yang memiliki wawasan gender dalam perspektif Islam masih minim sehingga belum banyak SDM yang memiliki keterampilan analisis gender; keempat, minimnya media KIE yang berdampak pada rendahnya dukungan masyarakat terhadap PUG bidang pendidikan Islam; Kelima, belum tersedianya alokasi anggaran secara khusus (gender budget) hingga tingkat satuan pendidikan.

Dilihat dari respon dalam bentuk kebijakan di tingkat kementerian, Kemendiknas dalam hal ini lebih progresif jika dibandingkan dengan 
Kemenag dalam menindaklanjuti Inpres No. 9/2000 dan Permendagri No. 15/2008. Kemendiknas telah melakukan langkah-langkah kongkrit dalam bentuk: pertama, mengeluarkan Permendiknas No. 84 tahun 2008 Tentang Pedoman Pelaksanaan Pengarusutamaan Gender Bidang Pendidikan; kedua, memiliki Renstra tahun 2010-2014 yang secara eksplisit mencantumkan "kesetaraan gender"; ketiga, memiliki Pokja PUG bidang pendidikan tingkat nasional, provinsi, dan sebagian ditingkat kabupaten/ kota. Ketiga langkah strategis tersebut ternyata belum dilakukan oleh Kemenag.

Para pengambil kebijakan bidang pendidikan Islam perlu merevitalisasi pendidikan Islam sebagai entry point pengembangan epistemologi pendidikan Islam, khususnya dalam implementasi PUG. Langkah strategis ini perlu dilakukan agar proses akselerasi dalam mewujudkan kesetaraan dan keadilan gender bidang pendidikan Islam di semua level pendidikan menjadi kenyataan. Revitalisasi yang dimaksud mencakup aspek kebijakan responsif gender, misalnya pelatihan PUG bidang pendidikan bagi stakeholder pendidikan Islam untuk semua jenjang pendidikan, serta penyediaan anggaran responsif gender (gender budget). Kemudian ditindaklanjuti oleh Kepala Madrasah melalui pembenahan manajemen dan budaya ramah gender, kurikulum pendidikan Islam. Para guru juga melakukan inovasi dalam pembelajaran di kelas, penyediaan buku ajar dan media pembelajaran responsif gender.

\section{DAFTAR RUJUKAN}

Achmad Khan, Irfan. "Elemen-elemen Empiris, Intuitif, dan Rasional Terjalin dalam Pengetahuan Kita: The Islamic Method" dalam Muhammad Muqim (ed.). Research Methodology in Islamic Perspective. New Delhi: Institute of Objective Studies, 1994.

Andersen, Margaret L. Thinking about Women Sociological Perspectives on Sex and Gender. New York: Macmillan Publishing Company, 1988. 
Dwi Astuti Nurhaeni, Ismi. "Efektifitas Regulasi Permendiknas No. 84 Tahun 2008 tentang Pengarusutamaan Gender Bidang Pendidikan (Studi Kasus di Kab. Kebumen)." Yustisia, Tahun 2009.

Hilary M, Lips. Sex \& Gender: An Introduction. London: Mayfield Publishing Company, 1993.

Imam Tholkhah. "Kebijakan PUG dalam Penyelenggaraan Pendidikan Islam." Makalah disampaikan pada Temu Karya Pengarusutamaan Gender Bidang Pendidikan Islam, tidak dipublikasikan, Yogyakarta, 2 Juni 2009.

Langgulung, Hasan. Azas-azas Pendidikan Islam. Jakarta: Pustaka AlHusna, 1988.

Langgulung, Hasan. Beberapa Pemikiran tentang Pendidikan Islam. Bandung: Al-Ma'arif, 1979.

MufidahCh. "Hasil Evaluasi Implementasi PUG Bidang Pendidikan Islam."

Monev Pilot Project Pengarusutamaan Gender Bidang Pendidikan Islam di DI Yogyakarta, 5-6 Maret 2010, Program Kemitraan Kementerian Agama dengan MCPM-AIBEP, 2010.

Mufidah Ch.Bingkai Sosial Gender: Islam, Strukturasi, dan Konstruksi Sosial. Malang: UIN Maliki Press, 2009.

Mufidah Ch. Gender di Pesantren Salaf, Why Not? Menelusuri Jejak

Konstruksi Sosial Pengarusutamaan Gender di Kalangan Elit

Santri. Malang: UIN Maliki Malang Press, 2010.

Panduan Pelaksanaan Inpres Nomor 9 Tahun 2000 tentang Pengarusutamaan Gender dalam Pembangunan Nasional.

Qomar, Mujamil. Epistimologi Pendidikan Islam: Dari Metode

Rasional hingga Metode Kritik. Jakarta: Erlangga, 2005.

Ruminiati. "Promosi Jabatan Kepala Sekolah Ditinjau dari Perspektif Gender: Penelitian Multi Situs di Berbagai Sekolah Dasar Swasta Bernuansa Agama dan Umum di Kota dan Kabupaten Malang Jawa Timur." Disertasi. Surabaya: PPS Universitas Airlangga, 2005.

Tafsir, Ahmad. Ilmu Pendidikan dalam Perspektif Islam. Bandung: PT. Remaja Rosdakarya, 2005.

Tim Penyusun. Hak Azasi Perempuan: Instrumen Hukum untuk Mewujudkan Keadilan. Jakarta: Yayasan Obor Indonesia, 2007. 
Tim Penyusun. Membangun Relasi Setara antara Perempuan dan Lakilaki Melalui Pendidikan Islam. Jakarta: Direktorat Jenderal Pendidikan KementerianAgama - Australia Indonesia Partnership, 2010.

Tim Penyusun. Panduan Pelaksanaan Inpres Nomor 9 Tahun 2000 tentang Pengarusutamaan Gender dalam Pembangunan Nasional. Jakarta: Kementerian Pemberdayaan Perempuan, 2002.

Tim Penyusun. Panduan Pengarusutamaan Gender Bidang Pendidikan: Buku II Kebijakan Pengarusutamaan Gender Bidang Pendidikan. Malang: Indonesia - Australia Partnership in Basic Education, 2007. 